\title{
Perancangan dan Pengembangan Sistem Informasi Perpustakaan Berbasis Web (Studi Kasus Jurusan Sistem Komputer)
}

\author{
Febi Andrea Renatha ${ }^{1)}$, Kodrat Iman Satoto ${ }^{2)}$, Oky Dwi Nurhayati ${ }^{2)}$ \\ Jurusan Sistem Komputer, Fakultas Teknik, Universitas Diponegoro \\ J1. Prof. Sudharto, Tembalang, Semarang \\ Email: febiandrea@ rocketmail.com
}

\begin{abstract}
ABSTRAK
Perpustakaan merupakan tempat menyimpan sumber informasi seperti buku dan sumber informasi lainnya selain buku. Seiring dengan perkembangan jaman sumber informasi yang tersedia semakin beragam. Hal ini menjadi alasan perlunya sebuah sistem informasi perpustakaan. Sistem informasi perpustakaan ini juga disebut dengan sistem informasi perpustakaan digital atau digital library. Salah satu tujuan dirancang dan diimplementasikan sistem informasi perpustakaa di Jurusan Sistem Komputer adalah untuk meningkatkan efisiensi kerja perpustakaan yang semula menggunakan sistem manual menjadi sistem informasi berbasis web untuk membantu pengolahan database dan mempermudah anggota dalam mencari informasi.

Dalam membuat digitial library ini menggunakan PHP sebagai program aplikasi dan MySQL sebagai server basis data yang sudah terangkum dalam satu aplikasi XAMPP dan dilengkapi dengan alat bantu barcode scanner untuk mengidentifikasi kode buku dan bacaan lainnya. Perancangan sistem informasi perpustakaan ini menggunakan metode waterfall yang terdiri dari kebutuhan pengguna, analisis, rancangan, implementasi dan pengujian. Permodelan sistem informasi ini menggunakan sistem melalui diagram yang terdiri dari flowchart, data flow diagram dan entity relationship diagram. Serta menggunakan teknologi barcode scanner untuk mengidentifikasi kode yang terdapat didalam buku.

Dengan adanya sistem informasi perpustakaan berbasis web ini diharapakan semakin banyak anggota terutama mahasiswa yang berkunjung ke perpustakaan Jurusan Sistem Komputer. Dipenelitian sistem informasi perpustakaan selanjutnya dapat dikembangkan dengan menggunakan teknologi Radio Frequency Identification (RFID).
\end{abstract}

Kata kunci : Perpustakaan, Sistem Informasi Berbasis web, PHP, MySQL, XAMPP, waterfall, barcode scanner, RFID.

\section{I.Pendahuluan \\ I.I Latar Belakang}

Perpustakaan dalam pengertian sederhana, memiliki arti sebuah koleksi buku dan majalah. Dapat juga diartikan sebagai koleksi pribadi perseorangan, namun perpustakaan lebih umum dikenal sebagai sebuah koleksi besar yang dibiayai dan dioperasikan oleh sebuah kota atau institusi dan dapat dimanfaatkan oleh masyarakat. Perpustakaan dapat juga diartikan sebagai kumpulan informasi yang bersifat ilmu pengetahuan, hiburan, rekreasi dan ibadah yang merupakan kebutuhan hakiki manusia. Seiring dengan perkembangan jaman perpustakaan tidak hanya ,menyimpan buku-buku saja, tetapi menyimpan informasi atau data yang dapat diakses ke map, mencetak informasi yang diinginkan, microfilm, tape audio, tape video, CD dan DVD. Perpustakaan di Jurusan Sistem Komputer masih menggunakan sistem yang manual, maka perlu dirubah menjadi perpustakaan yang lebih baik secara sistem informasinya.

Perlunya dibuat Sistem Informasi berbasis web di Jurusan Sistem Komputer ini bertujuan mempermudah setiap anggota untuk mendapatkan informasi atau bahan bacaan yang dibutuhkan. Perancangan dan pengembangan sistem informasi berbasis web inilah yang menjadi latar belakang penulisan tugas akhir ini dan membuat perpustakaan di Jurusan Sistem Komputer ini menjadi perpustakaan digital.
Perpustakaan digital ( digital library ) adalah perpustakaan yang mempunyai koleksi buku yang sebagian besar dalam format digital dan bisa diakses dengan menggunakan komputer. Isi dari perpustakaan digital ini berada dalam suatu komputer server yang bisa ditempatkan secara lokal maupun dilokasi yang jauh, namun dapat diakses dengan cepat dan mudah lewat jaringan komputer.

\subsection{Rumusan Masalah}

Berdasarkan latar belakang masalah tersebu, dapat dibuat suatu rumusan masalah, yaitu : "Bagaimana merancang dan mengimplementasikan Sistem Informasi Perpustakaan di Jurusan Sistem Komputer berbasis web dengan baik?".

\subsection{Batasan Masalah}

Dalam pembuatan tugas akhir ini, perancangan dan pengembangannya diharapkan dapat mencapai sasaran dan tujuan, maka permasalahannya akan dibatasi sebagai berikut :

1. Aplikasi yang dibuat ini dapat menyajikan informasi bagi mahasiswa, karyawan ataupun pihak administrasi perpustakaan itu sendiri. Informasi - informasi itu daftar buku, daftar pengarang, daftar koleksi, daftar anggota dan administrasi perpustakaan, proses peminjaman, proses pengembalian dan laporan - laporan yang berhubungan dengan kegiatan diperpustakaan. 
2. Aplikasi sistem informasi perpustakaan ini dibangun berbasis web dengan menggunakan Bahasa pemrograman PHP dan database MySQL.

\subsection{Tujuan Tugas Akhir}

Tujuan dari tugas akhir ini adalah merancangan dan mengembangkan sistem informasi perpustakaan di Jurusan Sistem Komputer yang bertujuan untuk meningkatkan efisiensi kerja perpustakaan yang semula menggunakan sistem manual menjadi sistem informasi yang berbasis web untuk membantu pengolahan database dan memudahkan anggota dalam mencari referensi.

\section{Tinjuan Pustaka \\ 2.1 Tinjaun Pustaka}

Perpustakaan merupakan tempat atau sarana untuk mendapatkan ilmu selain dari kegiatan belajar mengajar disekolah maupun universitas. Pada dasarnya perpustakaan merupakan bagian dari suatu bangsa, khususnya yang berkenaan dengan budaya literasi, budaya baca, budaya tulis, dokumentasi dan informasi.

Dengan seiring perkembangan jaman, informasi yang tersebar semakin cepat dan beragam. Teknologi informasi banyak digunakan untuk pengelolaan pekerjaan karena daya efektivitas dan efisiensinya yang sudah terbukti mampu mempercepat kinerja. Hal ini menjadi sebab penggunaan dan penerapan teknologi komputer disuatu instansi menjadi ukuran kemajuan, tidak terkecuali perpustakaan.

\subsection{Dasar Teori \\ 2.2.1 Sistem Informasi}

Menurut Laundon (2008), sistem informasi merupakan sekumpulan komponen yang saling berhubungan dan berfungsi untuk mengumpulkan, memproses, menyimpan dan mendistribusikan informasi untuk membantu mendukung pengambilan keputusan, menganalisis dan mengambarkan masalah yang kompleks dalam suatu organisasi.

\subsubsection{Sistem Informasi Perpustakaan}

Sistem informasi perpustakaan adalah suatu sistem didalam organisasi pelayanan publik yang mempertemukan kebutuhan pengelolaan transaksi peminjaman, pengembalian dan perpanjang buku, dan pembuatan laporan harian, bulanan ataupun tahunan guna mendukung operasi bersifat manajerial dan kegiatan dari suatu organisasi (Beiling, 2007).

\subsubsection{Basis Data}

Basis data adalah kumpulan data yang umumnya menjabarkan aktivitas - aktivitas dari satu atau lebih organisasi yang terkait ( Ramakrishnan, 2000). Basis data merupakan kumpulan dari item data yang saling berhubungan satu dengan yang lainnya yang diorganisasikan berdasarkan sebuah skema atau struktur tertentu, tersimpan di hardware komputer dengan software untuk melakukan manipulasi untuk kegiatan tertentu.

\subsubsection{Flowchart}

Flowchart merupakan suatu diagram yang mengambarkan alur kerja suatu sistem. Hubungan antar proses digambarkan dengan garis penghubung (Zarlis, 2007).

\subsubsection{Data Flow Diagram (DFD)}

Data flow diagram adalah teknik grafis yang mengambarkan aliran informasi dan transformasi yang diaplikasikan pada saat data bergerak dari input menjadi output. DFD merupakan alat yang cukup popular dewasa ini, karena dapat menggambarkan arus data didalam sistem dengan terstruktur dan jelas ( Whitekom, 2003).

\subsubsection{Entity Relationship Diagram (ERD)}

Entity relationship diagram adalah sebuah model data yang menggunakan beberapa notasi untuk menggambarkan data dalam hal entitas dan relasi yang digambarkan oleh data tersebut.

\subsubsection{MySQL}

$M y S Q L$ merupakan software sistem manajemen basis data (Database Management Sistem-DBMS) yang sangat popular di kalangan pemrogram web. $M y S Q L$ merupakan basis data yang paling popular digunakan untuk membangun aplikasi web yang menggunakan basis data sebagai sumber dan pengelola datanya (Ariasari, 2010).

\subsubsection{PHP}

PHP merupakan bahasa pemrograman berbentuk script yang ditempatkan dalam server dan diproses di server yang pertama kali dibuat oleh Rasmus Lerdorf pada tahun 1995. Hasil dari pengolahan akan dikirimkan ke klien, tempat pemakai menggunakan browser. Secara khusus, PHP dirancang untuk membentuk web dinamis. Artinya, ia dapat membentuk suatu tampilan berdasarkan permintaan terkini. Misalnya, bisa menampilkan isi basis data ke halaman web (Lee, 2007).

Selain dapat digunakan untuk berbagai sistem operasi dan bersifat opensource. PHP ternyata memiliki banyak kelebihan yang tidak dimiliki oleh bahasa script sejenis, yaitu:

1. PHP dapat digunakan pada semua jenis sistem operasi seperti Windows, Linux, dan lain-lain

2. PHP memiliki kemampuan untuk mengolah keluaran gambar, file berformat pdf, dan movies Flash

3. PHP didukung oleh banyak Database Management System (DBMS) seperti MySQL, Oracle, dan lain-lain.

\subsubsection{Teknologi Barcode}

Sebuah kode batang atau barcode adalah susunan garis cetak vertikal hita, putih dengan lebar berbeda untuk menyimpan data - data spesifik seperti kode produksi, nomor identitas dan lainnya, sehingga komputer dapat mengidentifikasi dengan informasi yang dikodekan dalam barcode.

ISBN ( Internasional Standard Book Number ) didefinisikan sebagai kode pengidentifikasian buku yang bersifat unik. Informasi tentang judul, penerbit dan kelompok penerbit tercakup dalam ISBN. ISBN terdiri dari deretan angka 13 digit, sebagai pemberi identifikasi terhadap satu judul buku yang diterbitkan oleh penerbit. Oleh karena itu, satu nomor ISBN untuk satu buku akan 
berbeda dengan nomor ISBN untuk buku yang lain. ISBN awalnya terdiri dari 10 digit nomor dengan urutan penulisan adalah kode negara-kode penerbit-kode bukuno identifikasi. Namun, mulai bulan Januari 2007, penulisan ISBN mengalami perubahan mengikuti pola EAN, yaitu 13 digit nomor. Perbedaannya hanya terletak pada tiga digit nomor pertama ditambah 978. Jadi, penulisan ISBN 13 digit adalah 978-kode negara-kode penerbit-kode buku-no identifikasi. Prefiks ISBN untuk negara Indonesia adalah 979 dan 602.

\section{Perancangan Sistem \\ 3.1 Data Penelitian}

Pembuatan sistem informasi perpustakaan ini memerlukan data-data yang digunakan untuk merancang data apa saja yang diperlukan untuk merancang sistem informasi perpustakaan ini.

1. Data Anggota, data terdiri dari NIM, Nama, Jenis Kelamin, Angkatan serta Alamat, Data ini nantinya digunakan untuk melakukan pendaftaran anggota perpustakaan baru untuk mendapatkan username dan password .

2. Data Buku, data ini terdiri dari No Stanbuk, Judul, Pengarang, Penerbit, Tahun Edisi, Jumlah Eksemplar. Data ini berfungsi sebagai informasi buku tersebut.

3. Data Jurnal, data ini terdiri dari No Jurnal, Judul, Pengarang, Tanggal, Deskripsi, Jumlah Eksemplar dan File PDF.

4. Data Majalah, data ini terdiri dari No Majalah, Judul, Pengarang, Tanggal, Deskripsi, Jumlah Eksemplar dan File PDF.

5. Data Tugas Akhir, data ini terdiri dari No Tugas Akhir, Judul, Pengarang, Tanggal, Deskripsi, Jumlah Eksemplar dan File PDF.

6. Data Transaksi Peminjaman dan Pengembalian. Data ini berisikan : Tanggal Peminjaman, ID Peminjam, Tanggal Kembali, No Buku yang dipinjam, lama pinjam dan denda. Dari data tersebut petugas dan anggota yang meminjam buku mendapatkan informasi tanggal berapa dan denda yang didapat apabila dalam pengembalian bukunya terlambat.

7. Data Petugas, data ini berisi No Petugas, Nama, Jenis Kelamin, Alamat dan No Telpon.

\subsection{Langkah - Langkah Perancangan}

Dalam merancang sebuah sistem diperlukan alur kerja. Alur kerja tersebut menghubungkan antar proses yang digambarkan dengan garis penghubung. Alur tersebut yang nantinya dijadikan acuan dalam merancang sistem informasi perpustakaan ini.

\subsection{Analisis Kebutuhan}

Analisis kebutuhan merupakan tahapan awal dalam pembangunan sebuah perangkat lunak. Analisis kebutuhan bertujuan untuk memahami kebutuhan dari sistem yang akan dibuat dan mengembangkan kebutuhan tersebut dengan mengumpulkan kebutuhan akan diinformasi yang diperlukan dalam membangun sistem informasi perpustakaan ini. Analisis kebutuhan terdiri dari dua jenis kebutuhan fungsional dan kebutuhan nonfungsional.

\subsubsection{Kebutuhan Fungsional}

Kebutuhan fungsional berisikan proses-proses apa saja yang dilakukan oleh sistem. Proses-proses tersebut adalah sebagai berikut :

1. Pendaftaran anggota :

- Apabila ini menjadi anggota perpustakaan, maka anggota tersebut melapor ke petugas perpustakaan.

- Petugas akan memasukan NIM, nama, jenis kelamin, angkatan dan alamat anggota baru.

- Setelah mendaftar anggota baru tersebut mendapatkan hak akses untuk dapat mengakses sistem informasi perpustakaan dan mendapatkan referensi Sistem dapat menampilkan data anggota.

- Sistem dapat menampilkan laporan data anggota.

2. Pendataan petugas perpustakaan :

- Pendataan ini dilakukan oleh admin.

- Admin mendata petugas dengan mengisi no petugas, nama, jenis kelamin, alamat dan no telepon.

- Admin dapat mengatur status dari setiap petugas.

- Admin dapat menampilkan data links didalam sistem.

3. Pendataan buku dan referensi lainnya :

- Petugas memasukan informasi tentang buku atau referensi lainnya yang meliputi no buku atau no ID, judul, pengarang, penerbit, tahun edisi, jumlah eksemplar.

- Petugas dapat menghitung jumlah buku yang tersedia.

- Petugas dapat menampilkan data buku berdasarkan kategori tertentu.

- Petugas dapat menampilkan buku atau referensi lainnya yang sering dipinjam.

- Petugas dapat memasukan data buku baru.

- Petugas dapat menghapus data buku.

4. Pendataan transaksi peminjaman :

- Sistem dapat melakukan transaksi peminjaman.

- Sistem dapat menampilkan tanggal kembali secara otomatis.

- Sistem dapat mencetak hasil transaksi peminjaman.

- Sistem dapat mengetahui buku yang dipinjam sudah dikembalikan atau belum. 
- Sistem dapat menampilkan data peminjam.

5. Pendataan transaksi pengembalian:

- Sistem dapat melakukan transaksi pengembalian buku.

- Sistem dapat menampilkan transaksis pengembalian.

- $\quad$ Sistem dapat menampilkan denda yang harus dibayar apabila belum dikembalikan.

- Sistem dapat menampilkan data peminjam yang buku dan menampilkan data buku.

- Sistem dapat mencetak hasil transaksi pengembalian.

\subsection{Perancangan Perangkat Lunak}

Perancangan perangkat lunak ini menggunakan metode pemodelan pemrograman terstruktur yaitu DFD (Data Flow Diagram). Proses ini menterjemahkan kebutuhan kedalam sebuah model perangkat lunak yang dapat diperkirakan kualitasnya sebelum dimulainya implementasi sistem.

\subsubsection{Diagram Konteks}

Diagram konteks merupakan diagram alir dan sebuah informasi yang menggambarkan sistem dalam satu lingkaran serta menggambarkan proses dalam suatu sistem secara keseluruhan. Gambar 3.2 menunjukkan diagram konteks sistem informasi perpustakaan.

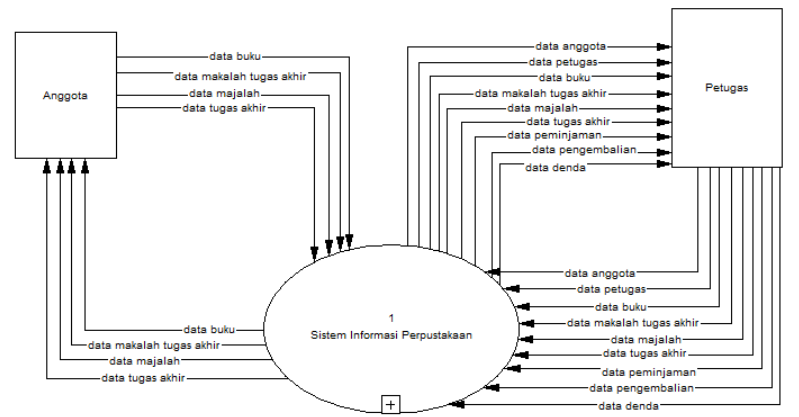

Gambar 3.1 Diagram Konteks

\subsubsection{DFD Level 1}

Data Flow Diagram menggambarkan sistem sebagai jaringan kerja antar fungsi yang berhubungan satu sama lain dengan aliran dan penyimpanan data. Pada gambar 3.3 DFD level 1 tersebut terdapat beberapa proses yang dilakukan oleh admin dan petugas.

Admin melakukan empat proses, antara lain :

1. Proses 1, admin dapat melakukan proses manajemen petugas. Admin dapat mengisikan data petugas. Admin juga memberikan hak akses untuk melakukan serta memberikan username dan password.

2. Proses 2, admin dapat melakukan proses manajemen status petugas. Admin memberikan status masing-masing petugas.
3. Proses 3, laporan data petugas. Admin memberikan laporan data-data petugas yang telah diberikan hak akses dengan mengisikan data-data petugas tersebut dan laporan tersebut dapat dicetak.

4. Proses 4, manajemen links. Admin mengatur berbagai links yang ada didalam sistem informasi perpustakaan serta dapat menambah dan menghapus links mana saja yang diperlukan.

Petugas dapat melakukan 4 proses, antara lain :

1. Proses 1, manajemen anggota. Petugas dapat menambah dan menghapus anggota. Serta memberikan hak akses sebagai pengguna sistem informasi perpustakaan.

2. Proses 2, manajemen buku. Petugas dapat menambahkan dan menghapus data buku atau referensi lainnya yang ada diperpustakaan. Data buku ini dilengkapi informasi-informasi untuk mempermudah anggota.

3. Proses 3, manajemen transaksi. Transaksi didalam sistem informasi perpustakaan ini terdiri dari dua yaitu transaksi peminjaman dan transaksi pengembalian. Petugas dapat melakukan kedua transaksi tersebut.

4. Proses 4, manajemen laporan transaksi. Petugas melakukan manajemen laporan yang berkaitan dengan pergerakan buku atau referensi lainnya yang dilakukan oleh anggota perpustakaan serta dapat mencetak hasil laporan tersebut.

Anggota dapat melakukan 4 proses, antara lain:

1. Proses 1,login. Anggota yang baru mendaftar sebagai anggota perpustakaan akan mendapatkan haknya yaitu username dan password .

2. Proses 2, data buku. Setelah melakukan login sebgaia anggota perpustakaan, dapat melihat dan mencari referensi yang ada didalam sistem informasi perpustakaan.

3. Proses 3, transaksi peminjaman dan pengembalian. Anggota dapat meminjam buku atau referensi lainnya setelah melakukan proses melihat dan mencari. Dengan memasukan no anggota, anggota tersebut sudah dapat meminjam buku tersebut dan dapat mengembalikannya tepat waktu sesuai dengan tercantum didalam sistem. Apabila sudah jatuh tempo dari tanggal yang ditetapkan, maka anggota tersebut dikenakan denda.

4. Proses 4, denda. Denda yang dibayarkan harus sesuai dengan yang tercantum didalam sistem. 


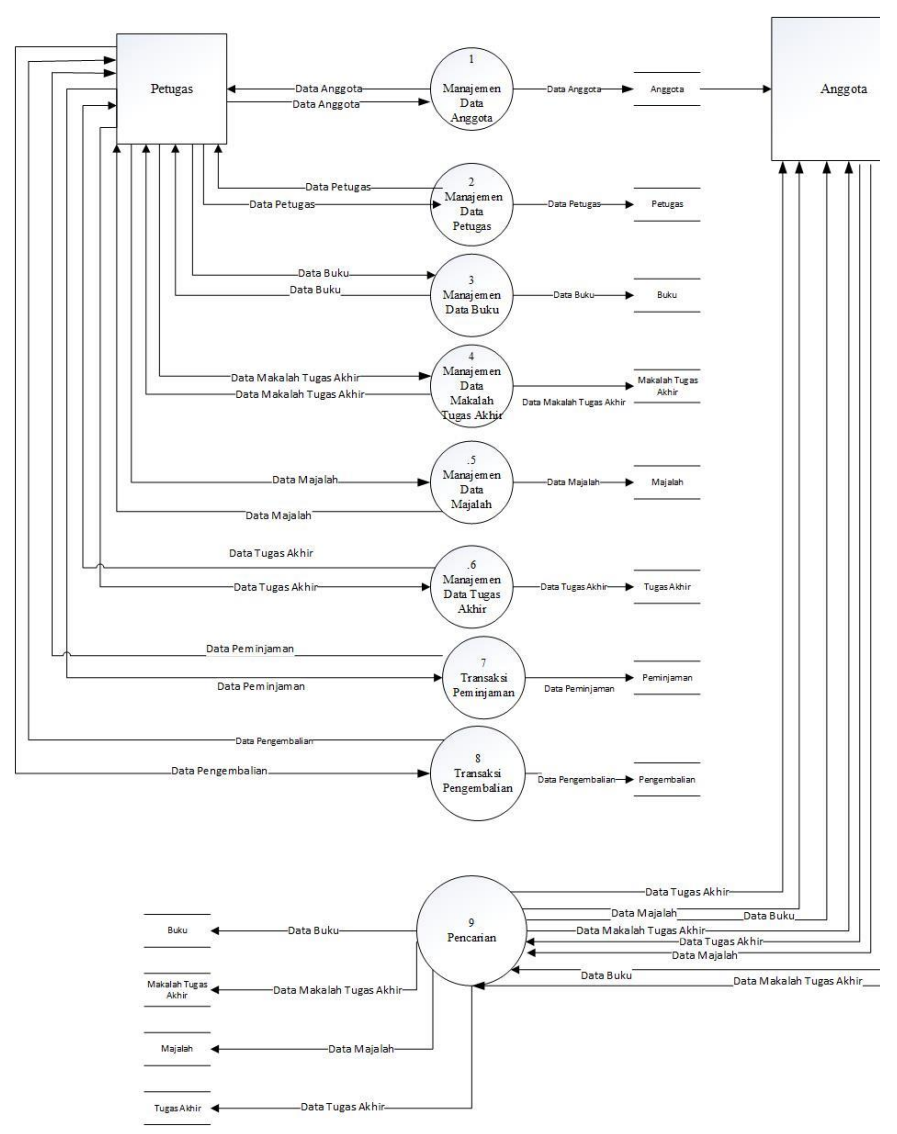

Gambar 3.2 Data Flow Diagram level 1

\subsection{Perancangan Basis Data}

Perancangan basis data untuk membuat sistem informasi perpustakaan dibutuhkan suatu pendekatan yang digunakan untuk menggambarkan hubungan antar data. Hubungan tersebu dapat dinyatakan dalam bentuk ERD (Entity Relationship Diagram).

\subsubsection{Entity Relationship Diagram ( ERD )}

Perancangan basis data menggunakan metode ERD, metode ini menyajikan data menggunakan Entity dan Relationship. Gambar 3.4 memperlihatkan ERD dari sistem informasi perpustakaan yang dirancang.

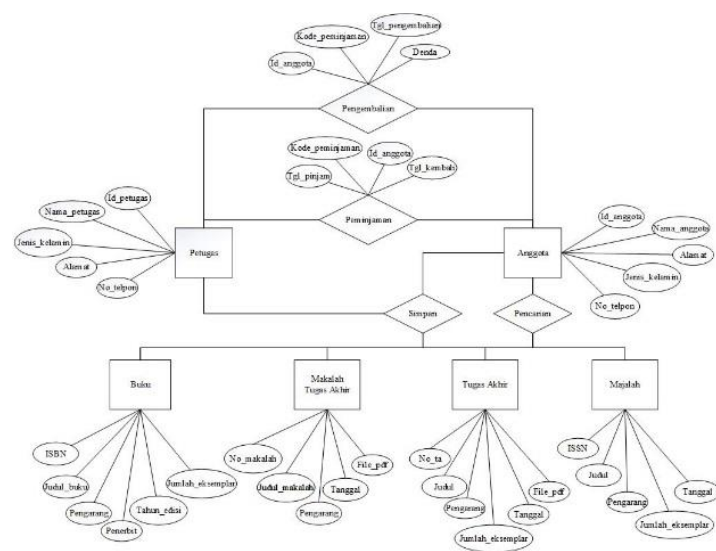

Gambar 3.3 Entity Relationship Diagram

\section{Pengujian Sistem dan Implementasi 4.1 Blackbox}

Tabel 4.1 adalah pengujian blackbox sistem informasi perpustakaan di Jurusan Sistem Komputer.

Tabel 4.1 Pengujian Blackbox

\begin{tabular}{|c|c|c|c|}
\hline Nama Pengujian & Bentuk Pengujian & $\begin{array}{c}\text { Hasil yang } \\
\text { diharapkan }\end{array}$ & Hasil pengujian \\
\hline $\begin{array}{l}\text { Pengujian menu } \\
\text { login }\end{array}$ & $\begin{array}{c}\text { Klik menu login } \\
\text { lalu memasukan } \\
\text { username dan } \\
\text { password }\end{array}$ & $\begin{array}{l}\text { Muncul halaman } \\
\text { utama sebagai } \\
\text { admin, petugas } \\
\text { atau anggota }\end{array}$ & Berhasil \\
\hline $\begin{array}{l}\text { Pengujian menu } \\
\text { master data }\end{array}$ & $\begin{array}{c}\text { Klik menu master, } \\
\text { pilih salah satu sub } \\
\text { menu yang akan } \\
\text { diinputkan datanya }\end{array}$ & $\begin{array}{l}\text { Muncul tampilan } \\
\text { tambah data, data } \\
\text { berhasil disimpan }\end{array}$ & Berhasil \\
\hline $\begin{array}{l}\text { Pengujian menu } \\
\text { Pencarian data }\end{array}$ & $\begin{array}{c}\text { Klik menu } \\
\text { pencarian, pilih } \\
\text { salah satu sub } \\
\text { menu data yang } \\
\text { dicari }\end{array}$ & $\begin{array}{l}\text { Muncul tampilan } \\
\text { pencarian data }\end{array}$ & Berhasil \\
\hline $\begin{array}{c}\text { Pengujian menu } \\
\text { Transaksi }\end{array}$ & $\begin{array}{c}\text { klik menu } \\
\text { transaksi, pilih } \\
\text { salah satu sub } \\
\text { menu transaksi } \\
\text { pinjam-kembali } \\
\text { buku } \\
\end{array}$ & $\begin{array}{l}\text { Muncul tampilan } \\
\text { transaksi data }\end{array}$ & Berhasil \\
\hline $\begin{array}{l}\text { Pengujian menu } \\
\text { Laporan }\end{array}$ & $\begin{array}{c}\text { Klik menu laporan, } \\
\text { pilih salah satu sub } \\
\text { data yang akan } \\
\text { dilaporkan lalu } \\
\text { cetak } \\
\end{array}$ & $\begin{array}{l}\text { Muncul tampilan } \\
\text { laporan data dan } \\
\text { cetak data }\end{array}$ & Berhasil \\
\hline $\begin{array}{c}\text { Pengujian menu } \\
\text { Logout }\end{array}$ & Klik menu logout & $\begin{array}{c}\text { Kembali halaman } \\
\text { utama / home }\end{array}$ & Berhasil \\
\hline
\end{tabular}

Halaman utama Sistem Informasi Perpustakaan

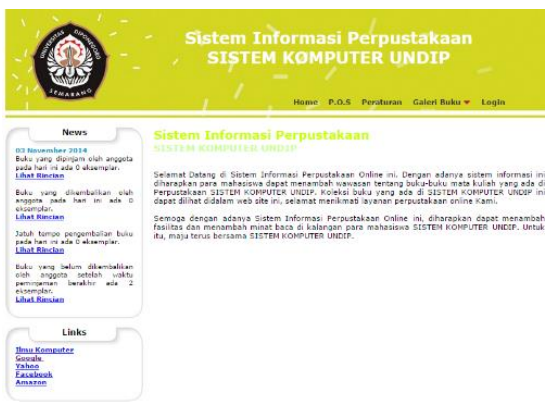

Gambar 4.1 Tampilan halaman utama Sistem Informasi Perpustakaan

Pada gambar 4.1 diatas terdapat beberapa menu utama, diantaranya adalah Home, P.O.S (Peraturan Operasional Standar sebuah perpustakaan), Peraturan yang merupakan tata tertib yang harus dipahami dan ditaati oleh setiap anggota perpustakaan, gallery buku yang berisi berbagai macam referensi mulai dari handbook, jurnal, majalah dan tugas akhir, menu login untuk admin ataupun petugas perpustakaan, news yaitu berita yang berikatan dengan Sistem Informasi Perpustakaan dan Links.

Pengujian Menu - Menu dalam Sistem Informasi Perpustakaan

\section{- Pengujian Menu Login sebagai Admin}




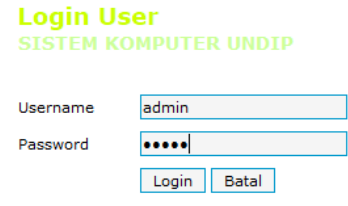

Gambar 4.2 Tampilan Login sebagai User (admin)

Gambar 4.2 menunjukkan tampilan Login sebagai user (admin). Login sebagai admin harus memasukkan kombinasi username dan password dengan benar. Setelah berhasil melakukan login, admin dapat melakukan akses sesuai dengan hak aksesnya. Didalam Sistem Informasi Perpustakaan ini hak akses yang dimilliki oleh admin adalah sebagai penambah data admin dan petugas serta memberikan hak akses.

- Pengujian Menu Input Data Petugas

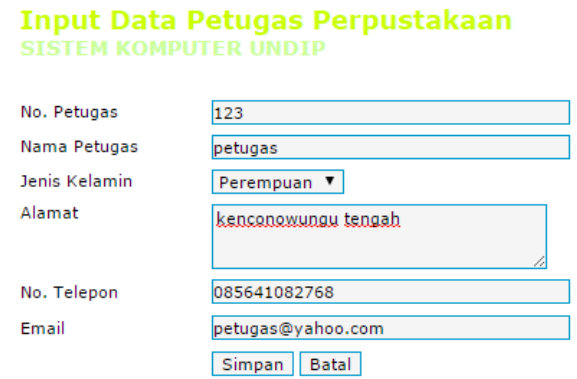

Gambar4.3 Tampilan Input Data Petugas

Pada gambar 4.3, admin melakukan hak aksesnya dengan menambah data petugas serta memasukkan informasi-informasi yang berhubungan dengan petugas.

\section{- Pengujian Menu Pencarian Data Petugas}

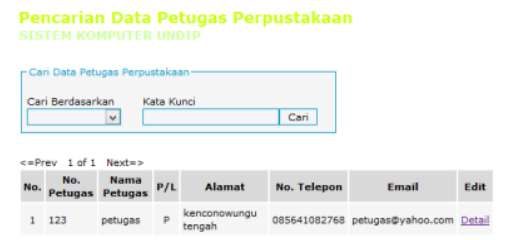

Gambar 4.4 Tampilan Pencarian Data Petugas

Gambar 4.4 merupakan tampilan dari pencarian datadata petugas perpustakaan. Admin memberikan hak akses kepada masing-masing petugas yang telah diinputkan, selain hak akses, admin juga dapat mengubah data dan menghapus data petugas jika diperlukan.

- Pengujian Menu Cetak Laporan Data Petugas
LAPORAN PETUGAS PERPUSTAKAAN

\begin{tabular}{|c|l|l|l|l|r|}
\hline No & No. Petugas & Nama Petugas & L/P & Alamat & No. Telepon \\
\hline 1 & 123 & petugas & & kenconowungu tengah & 085641082768 \\
\hline
\end{tabular}

Semarang, 04-11-2014

$\frac{\text { admin }}{\text { NIP. }}$

Gambar 4.5 Tampilan Cetak Laporan Petugas

Gambar 4.5 merupakan cetak hasil laporan petugas perpustakaan. Laporan petugas tersebut berisi informasiinformasi yang berhubungan dengan petugas. Laporan ini nantinya yang akan dipertanggungjawabkan kepada kepala perpustakaan.

\section{- Pengujian Menu Login sebagai Petugas}

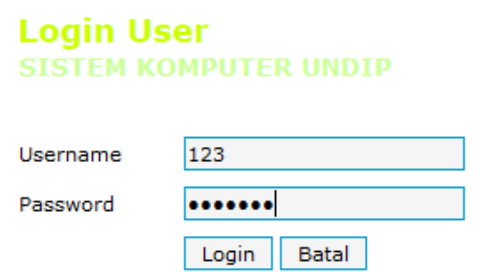

Gambar 4.6 Tampilan Login sebagai petugas

\section{- Pengujian Menu Input Data Anggota}

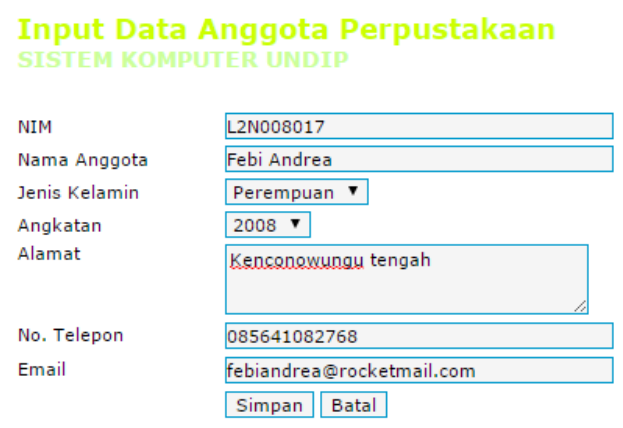

Gambar 4.7 Tampilan Input Data Anggota

Gambar 4.7 merupakan sub menu master data, yaitu penginputan data anggota baru perpustakaan. maupun karyawan memiliki hak yang sama apabila telah menjadi anggota perpustakaan. Gambar 4.7 menunjukkan tampilan input data anggota. Anggota perpustakaan yang dimaksud adalah mahasiswa Sistem Komputer. Mahasiswa yang ingin menjadi anggota perpustakaan cukup membawa data diri. Selain mahasiswa, karyawan Jurusan Sistem Komputer juga dapat menjadi anggota perpustakaan, yang membedakan adalah pada nomor identitasnya. Mahasiswa menggunakan NIM (Nomor Induk Mahasiswa) sedangkan karyawan menggunakan NIK (Nomor Induk Karyawan/Pegawai).

\section{- Pengujian Menu Input Data Buku}


Input Data Buku Perpustakaan

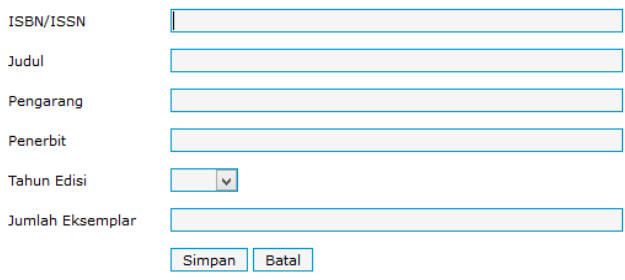

Gambar 4.8 Tampilan menu Input Data Buku

Gambar 4.8 masih merupakan sub menu master yang merupakan input data tentang buku baru yang ada diperpustakaan. Informasi-informasi yang terdapat didalam buku dicantumkan dalam sistem ini dengan tujuan mempermudah anggota perpustakaan dalam mencari referensi handbook. Selain buku, ada referensi lain seperti jurnal, majalah dan tugas akhir. Seperti jurnal, majalah dan tugas akhir, selain dapat dipinjam file .pdf yang dapat diunduh secara gratis.

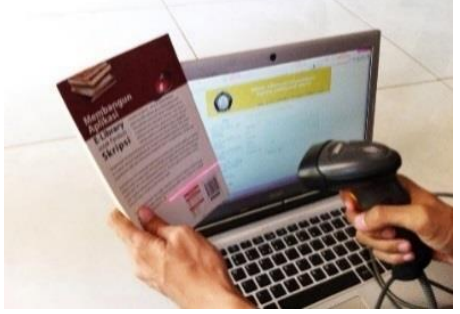

Gambar 4.9 Scanner Barcode Input Buku

Dalam memasukkan data buku, pertama dengan menggunakan Barcode Scanner nomor buku atau ISSN/ISSBN kita scan nomor tersebut seperti pada gambar 4.9.

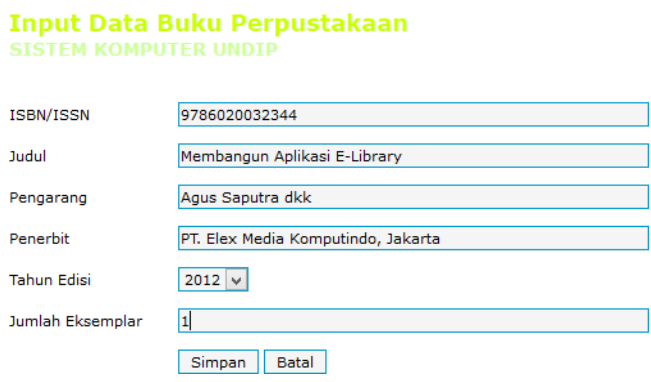

Gambar 4.10 Input Barcode Buku

Nomor ISSN/ISSBN yang telah discanner maka tampilan dari Sistem Informasi Perpustakaan dan isikan pula keterangan atau informasi dari sumber bacaan/ buku baru. Setelah mengisikan informasi yang berkaitan dengan buku maka tekan tombol simpan. Lalu data tersebut akan tersimpan dan memudahkan pencarian oleh anggota perpustakaan maupun petugas perpustakaan seperti gambar 4.10.

- Pengujian Menu Pencarian Data Mahasiswa
Pencarian Data Anggota Perpustakaan

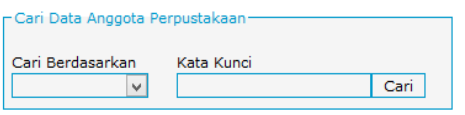

\begin{tabular}{|c|c|c|c|c|c|}
\hline No. & NIM & Nama Anggota & $\mathrm{P} / \mathrm{L}$ & Angkatan & Edit \\
\hline 1 & 21120110110033 & Bagus Lingga Tudanto & L & 2010 & Detail \\
\hline 2 & 21120110141009 & Indriani Wijiastuti & $P$ & 2010 & Detail \\
\hline 3 & 21120111130040 & Dini Indriyani Putri & P & 2011 & Detail \\
\hline 4 & 21120111130065 & Bagus Budi Santoso & L & 2011 & Detail \\
\hline 5 & L2N008001 & $\begin{array}{l}\text { Adhitama Ksatriya } \\
\text { Nugraha }\end{array}$ & L & 2008 & Detail \\
\hline 6 & L2N008002 & Afandi Nur Aziz Thohari & L & 2008 & Detail \\
\hline 7 & L2N008003 & Alifvia Arvi Ningrum & $\mathrm{P}$ & 2008 & Detail \\
\hline 8 & L2N008005 & Ambrina Kundyanirum & $\mathrm{P}$ & 2008 & Detail \\
\hline 9 & L2N008006 & Anggit Perdana & L & 2008 & Detail \\
\hline 10 & L2N008025 & Mohammad Rafli Zulfikar & $\mathrm{L}$ & 2008 & Detail _ \\
\hline
\end{tabular}

Gambar 4.11 Tampilan menu Pencarian Data Mahasiswa

Gambar 4.11 menunjukkan tampilan menu pencarian data mahasiswa. Menu pencarian merupakan menu untuk mencari data-data anggota perpustakaan seperti mahasiswa dan karyawan serta data-data daftar bacaan yang tersedia diperpustakaan seperti buku, jurnal, majalah dan tugas akhir. Terdapat menu edit didalam menu pencarian data, menu edit tersebut digunakan apabila terjadi kesalahan informasi yang berhubungan dengan anggota ataupun bacaan yang ada diperpustakaan.

\section{- Pengujian Menu Peminjama Buku}
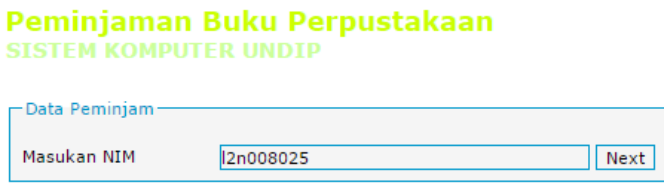

Gambar 4.12 Tampilan Menu Pinjam Buku

Gambar 4.12 merupakan tampilan menu pinjam buku, dengan memasukkan NIM maka akan muncul data peminjam buku

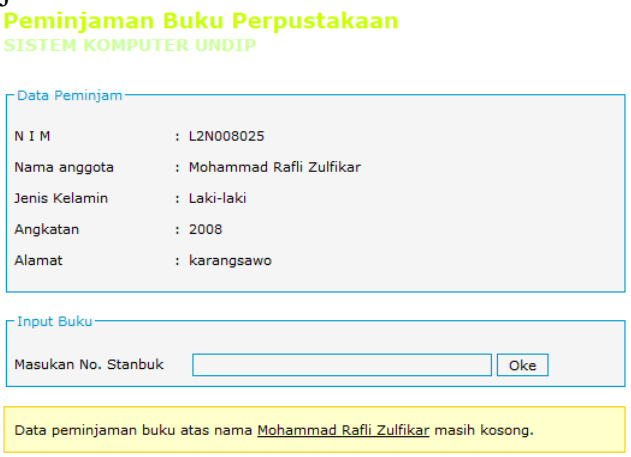

Gambar 4.13 Tampilan Data Peminjam Buku

Gambar 4.13 merupakan data dari peminjam buku. Lalu masukkan no. stanbuk ( ISSN/ISBN) buku atau bacaan lain yang akan dipinjam. 


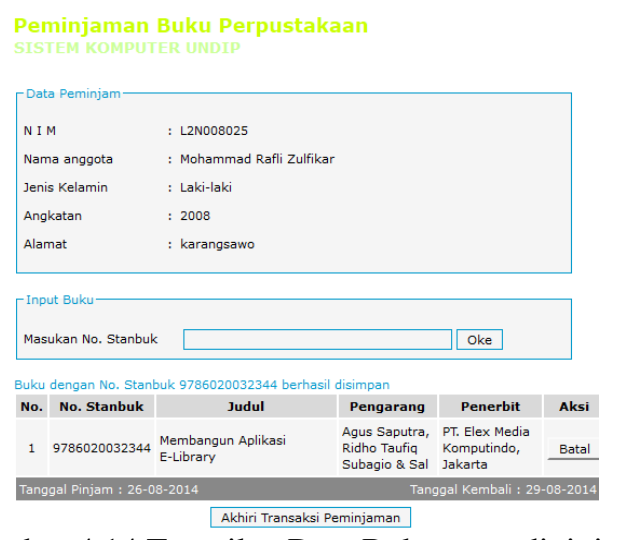

Gambar 4.14 Tampilan Data Buku yang dipinjam

- Pengujian Menu Pengembalian Buku

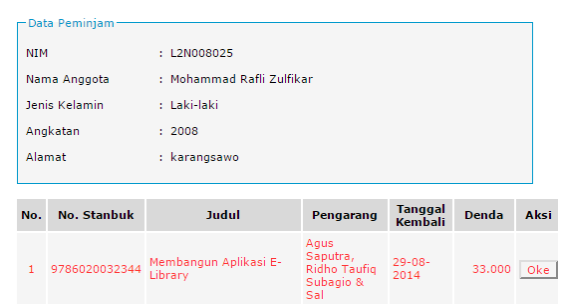

Gambar 4.15 Tampilan Menu Pengembalian Buku

Gambar 4.15 merupakan tampilan dari menu pengembalian buku. Data-data yang ditampilkan adalah informasi dari peminjam buku dan informasi dari buku atau bacaan lain yang dipinjam beserta tanggal pengembalian dan denda yang dikenakan tiap harinya. Apabila transaksi ini telah selesai maka petugas dapat menghapus data tersebut dan menginput data peminjam yang baru.

\section{- Pengujian Menu Laporan Data Anggota}

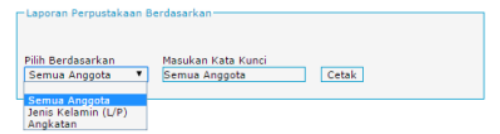

Gambar 4.16 Tampilan Menu Laporan Anggota

Gambar 4.16 merupakan tampilan dari menu laporan anggota perpustakaan. Pilih anggota berdasarkan semua anggota, jenis kelamin (P/L) dan angkatan lalu klik tombol cetak.

Setelah mengeklik cetak, maka akan ada tampilan seperti diatas. Laporan anggota perpustakaan ini merupakan semua anggota yang masih menjadi mahasiswa Jurusan Sistem Komputer. Laporan anggota ini nantinya yang dipertanggungjawabkan kepada kepala perpustakaan. Data yang terdapat didalam laporan ini meliputi NIM, nama, jenis kelamin, angkatan dan alamt. Selain mahasiswa, karyawan juga dapat dicetak datanya. Gambar 4.17 menunjukkan tampilan cetak data anggota.

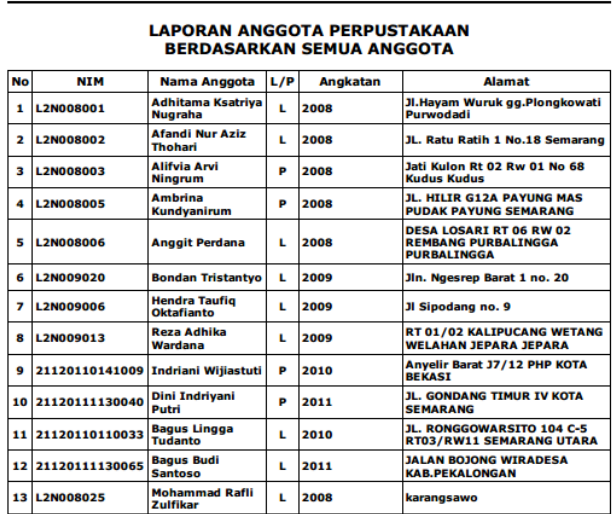

Semarang, 03-11-2014
Petugas Perpustakaan

Petugas

Gambar 4.17 Tampilan Cetak Laporan Anggota

\section{- Pengujian Menu Laporan Data Buku}
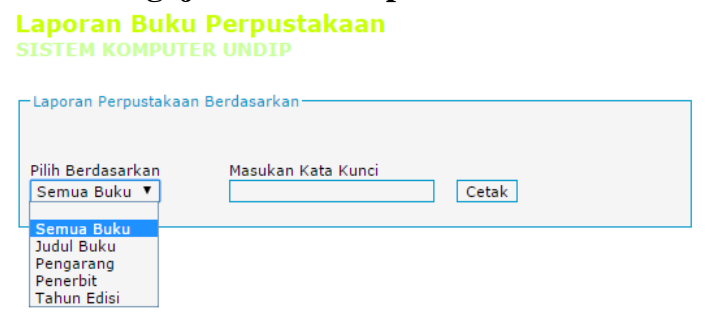

Gambar 4.18 Tampilan Menu Laporan Buku

Gambar 4.18 merupakan tampilan menu laporan buku, sama seperti menu laporan anggota. Pilih kategori berdasarkan semua buku, judul, pengarang, penerbit dan tahun edisi.

Setelah pilih salah satu kategori lalu klik cetak. Maka tampilannya akan sebagai berikut :

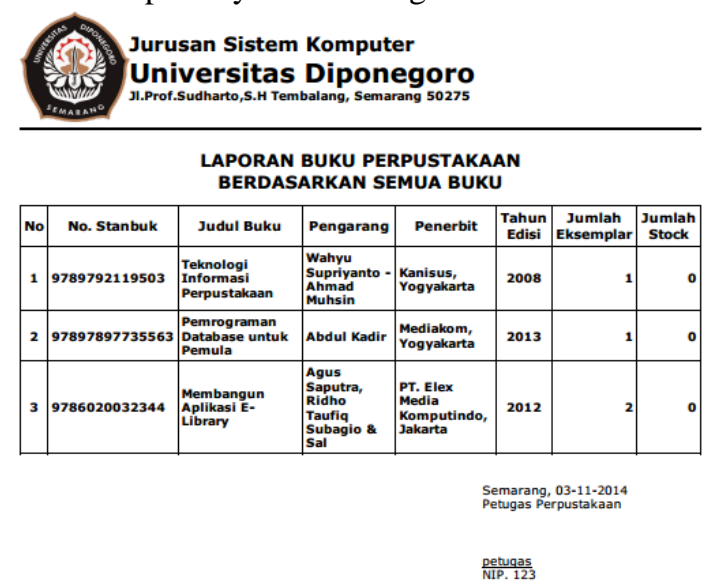

Gambar 4.19 Tampilan Cetak Laporan Buku

Gambar 4.19 merupakan hasil dari laporan buku berupa cetak laporan buku yang ada diperpustakaan. Data yang ada dicetak buku ini adalah no buku, judul buku, 
pengarang, penerbit, tahun edisi, jumlah eksemplar dan jumlah stock yang ada diperpustakaan.

\section{- Pengujian Menu Pembuatan Barcode}

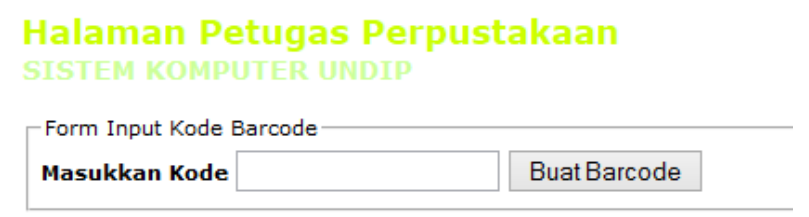

Gambar 4.20 Tampilan Menu Barcode

Gambar 4.20 merupakan tampilan menu pembuatan barcode. Menu tersebut digunakan untuk membuat barcode dari bacaan yang ada diperpustakaan seperti jurnal dan tugas akhir yang masing-masing belum memiliki barcode. Kode barcode tersebut dibuat oleh petugas perpustakan dengan mengacung dari aturanaturan cara membuat kode barcode.

- Pengujian Menu Laporan Peminjaman Buku

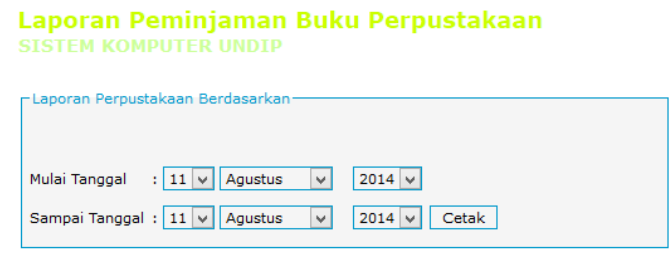

Gambar 4.21 Tampilan Menu Laporan Peminjam Buku

Gambar 4.21 merupakan tampilan menu laporan peminjam buku. Pilih tanggal pinjam lalu cetak laporan peminjam tersebut.

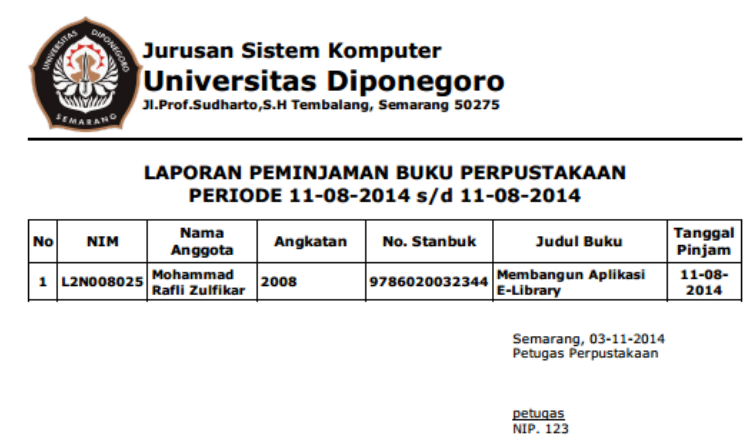

Gambar 4.22 Tampilan Cetak Laporan Peminjam Buku

Gambar 4.22 merupakan tampilan cetak data peminjam buku perpustakaan. Selain laporan data peminjam, didalam sistem informasi perpustakaan ini juga terdapat laporan data pengembalian buku. Sama halnya dengan data peminjam buku, informasi yang terdapat didalam data peminjam dan data pengembalian buku adalah data peminjam, data buku yang dipinjam serta jatuh tempo buku tersebut harus dikembalikan.

- Pengujian Menu Laporan Denda

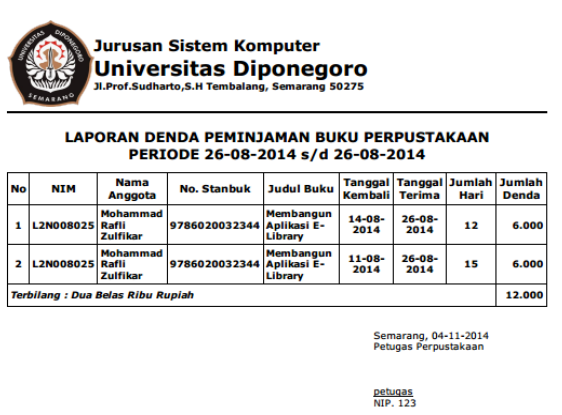

Gambar 4.23 Tampilan Menu Laporan Denda

$$
\text { Peminjaman }
$$

Gambar 4.23 merupakan tampilan menu laporan denda peminjama buku perpustakaan. Sama seperti laporan peminjaman dan pengembalian buku, setelah mengisi tanggal yang telah ditentukan, lalu pilih cetak dan data yang diinginkan akan dapat dicetak.

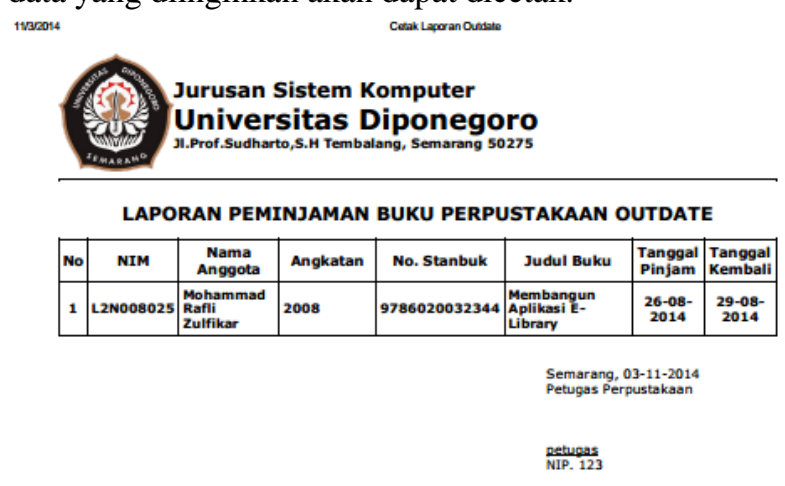

Gambar 4.24 Tampilan Cetak Laporan Outdate

Gambar 4.24 merupakan tampilan cetak laporan outdate dari referensi yang dipinjam. Laporan ini berisi data-data peminjam yang telah melewati jatuh tempo pengembalian buku beserta denda dari tanggal yang telah diitentukan. Laporan ini nantinya akan jadi laporan pertanggungjawaban kepada kepala perpustakaan.

\subsection{Perbandingan Aplikasi Sistem Informasi Perpustakaan dengan Penelitian Sebelumnya}

4.1 Tabel Perbandingan Aplikasi Sistem Informasi Perpustakaan dengan Penelitian Sebelumnya

\begin{tabular}{|c|c|c|}
\hline Perbedaan & $\begin{array}{c}\text { Penelitian } \\
\text { yang } \\
\text { Sebelumnya }\end{array}$ & $\begin{array}{c}\text { Penelitian yang } \\
\text { Sekarang }\end{array}$ \\
\hline $\begin{array}{l}\text { Lingkup } \\
\text { Penelitian }\end{array}$ & $\begin{array}{l}\text { Penelitian } \\
\text { dilakukan } \\
\text { dilingkup } \\
\text { Jurusan } \\
\text { Lingkungan } \\
\text { Fakultas } \\
\text { Teknik } \\
\text { Universitas } \\
\text { Diponegoro. }\end{array}$ & $\begin{array}{lr}\text { Penelitian } & \text { dilakukan } \\
\text { dilingkup Jurusan Sistem } \\
\text { Komputer } & \text { Fakultas } \\
\text { Teknik } & \text { Universitas } \\
\text { Diponegoro. } & \end{array}$ \\
\hline Hak akses & $\begin{array}{l}\text { Hak akses yang } \\
\text { diberikan oleh }\end{array}$ & $\begin{array}{lll}\text { Setiap } & \text { karyawan } & \text { dan } \\
\text { dosen } & \text { yang berada }\end{array}$ \\
\hline
\end{tabular}




\begin{tabular}{|c|c|c|}
\hline & $\begin{array}{l}\text { admin kepada } \\
\text { setiap anggota } \\
\text { melalui tahap } \\
\text { pendaftaran diri } \\
\text { sebagai } \\
\text { anggota } \\
\text { perpustakaan. }\end{array}$ & $\begin{array}{l}\text { didalam lingkup Sistem } \\
\text { Komputer dapat } \\
\text { melakukan akses Sistem } \\
\text { Informasi ini tanpa harus } \\
\text { mendaftarkan diri sebagai } \\
\text { anggota perpustakaan, } \\
\text { cukup login menggunakan } \\
\text { nim ataupun id } \\
\text { mahasiswa, dosen dan } \\
\text { karyawan. }\end{array}$ \\
\hline & & $\begin{array}{l}\text { Didalam Sistem Informasi } \\
\text { ini, admin/user hanya } \\
\text { melakukan tugasnya } \\
\text { untuk memberikan hak } \\
\text { akses kepada setiap } \\
\text { petugas, anggota, } \\
\text { karyawan atau dosen. } \\
\text { Sedangkan yang bertugas } \\
\text { untuk mengatur anggota, } \\
\text { daftar bacaan dll adalah } \\
\text { petugas perpustakaan itu } \\
\text { sendiri. }\end{array}$ \\
\hline $\begin{array}{c}\text { Menambah } \\
\text { barcode }\end{array}$ & $\begin{array}{l}\text { Belum terdapat } \\
\text { menu yang } \\
\text { digunakan } \\
\text { untuk membuat } \\
\text { barcode. }\end{array}$ & $\begin{array}{l}\text { Terdapat menu membuat } \\
\text { barcode yang digunakan } \\
\text { untuk melengkapi bahan } \\
\text { referensi yang belum } \\
\text { terdapat barcode, seperti } \\
\text { tugas akhir dan jurnal. }\end{array}$ \\
\hline Menu Laporan & $\begin{array}{l}\text { Laporan yang } \\
\text { ditampilan } \\
\text { dalam bentuk } \\
\text { Excel terdapat } \\
\text { semua laporan } \\
\text { seperti anggota, } \\
\text { peminjaman, } \\
\text { pengembalian, } \\
\text { denda serta } \\
\text { laporan } \\
\text { terhadap buku } \\
\text { masuk } \\
\text { dijadikan satu, } \\
\text { tidak bisa } \\
\text { memilih } \\
\text { tanggal, bulan } \\
\text { serta tahun data } \\
\text { yang ingin } \\
\text { dicetak. }\end{array}$ & $\begin{array}{l}\text { Menu laporan ini berisi } \\
\text { sebagai berikut : } \\
\text { 1. Laporan jumlah } \\
\text { anggota yang } \\
\text { bisa langsung } \\
\text { dicetak } \\
\text { berdasarkan } \\
\text { semua } \\
\text { anggota/karyawa } \\
\text { n, jenis kelamin } \\
\text { dan angkatan. } \\
\text { Laporan hasil } \\
\text { peminjaman/ } \\
\text { pengembalian } \\
\text { buku atau } \\
\text { referensi lainnya } \\
\text { dapat dipilih } \\
\text { tanggal, bulan } \\
\text { dan tahun berapa } \\
\text { laporan yang } \\
\text { ingin dicetak. } \\
\text { Terdapat laporan } \\
\text { denda yang juga } \\
\text { dapat dipilih per } \\
\text { bulan atau } \\
\text { pertahun dan } \\
\text { terdapat } \\
\text { keterangan } \\
\text { anggota siapa } \\
\text { saja yang masih }\end{array}$ \\
\hline
\end{tabular}

\begin{tabular}{|c|c|c|}
\hline & & $\begin{array}{l}\text { mempunyai } \\
\text { kewajiban denda. }\end{array}$ \\
\hline $\begin{array}{c}\text { Menu } \\
\text { Transaksi } \\
\text { Peminjaman } \\
\text { dan } \\
\text { Pengembalian }\end{array}$ & $\begin{array}{l}\text { Transaksi yang } \\
\text { dilakukan oleh } \\
\text { semua anggota } \\
\text { perpustakaan, } \\
\text { menjadi satu } \\
\text { tidak ada } \\
\text { pemisah antara } \\
\text { anggota } \\
\text { perpustakaan } \\
\text { yang berstatus } \\
\text { mahasiswa, } \\
\text { karyawan } \\
\text { ataupun dosen. }\end{array}$ & $\begin{array}{ll}\text { Masing-masing } & \text { transaksi } \\
\text { yang dilakukan oleh } \\
\text { anggota atau karyawan } \\
\text { mempunyai } \\
\text { sendiri. }\end{array}$ \\
\hline $\begin{array}{c}\text { Menu } \\
\text { Pencarian Data }\end{array}$ & $\begin{array}{l}\text { Pencarian data } \\
\text { menggunakan } \\
\text { nama atau id } \\
\text { anggota } \\
\text { perpustakaan. }\end{array}$ & $\begin{array}{l}\text { Pencarian data anggota } \\
\text { yang berstatus mahasiswa } \\
\text { dapat dilakukan dengan } \\
\text { beberapa kategori nim, } \\
\text { nama, jenis kelamin, } \\
\text { angkatan, alamat, nomor } \\
\text { telpon dan email. Begitu } \\
\text { juga terhadap anggota } \\
\text { yang berstatus karyawan } \\
\text { dan referensi lain seperti } \\
\text { buku, majalah, jurnal dan } \\
\text { tugas akhir. }\end{array}$ \\
\hline
\end{tabular}

\section{Penutup}

\subsection{Kesimpulan}

Dari hasil perancangan dan implementasi Sistem Informasi Perpustakaan Jurusan Sistem Komputer maka dapat disimpulkan hal-hal sebagai berikut :

1. Sistem Informasi Perpustakaan merupakan $e$ library yang bertujuan untuk mempermudah mahasiswa ataupun karyawan dalam mencari sumber bacaan.

2. Sistem Informasi Perpustakaan dirancang dengan menggunakan pemrograman PHP dan basis data $M y S Q L$ yang berjalan pada web server Apache.

3. Sistem Informasi Perpustakaan memiliki dua user, yaitu admin dan petugas perpustakaan, sedangkan anggota hanya dapat mengakses sistem informasi ini tanpa harus login.

4. Sistem Informasi Perpustakaan menggunakan teknologi Barcode Scanner dapat digunakan untuk mengidentifikasi buku atau bacaan lainnya.

5. Sistem Informasi Perpustakaan dapat diakses dengan menggunakan web browser dan berdasarkan pengujian terhadap sistem informasi yang dibuat, seluruh fungsi menu yang ada didalam sistem tersebut telah berhasil sesuai dengan fungsinya.Alamat Sistem Informasi Perpustakaan Jurusan Sistem Komputer http://localhost/perpus/ . 


\subsection{Saran}

1. Sistem Informasi Perpustakaan dapat dikembangkan lebih lanjut agar sistem yang sudah berjalan dapat diakses secara lebih baik dan menambah fitur agar lebih lengkap.

2. Perlu dilakukan penelitian lebih lanjut untuk menyempurnakan sistem informasi ini untuk menambah proses dalam pendaftaran anggota baru.

3. Perlu dilakukan penelitian lebih lanut dalam menggunakan teknologi yang terbaru, yaitu teknologi Radio Frequency Identification (RFID). RFID dikembangkan sebagai pengganti atau penerus barcode.

\section{DAFTAR PUSTAKA}

1. Supriyanto, Wahyu dan Muhsin, Ahmad. 2008. Teknologi Informasi Perpustakaan. Yogyakarta : Kanisius.

2. Saputra, Agus, dkk. 2012. Membangun Aplikasi E-Library Untuk Panduan Skripsi. Jakarta : PT. Elex Media Komputindo.
3. Kadir, Abdul. 2013. Pemrograman Database MySQL. Yogyakarta : Mediakom.

4. Dian Sano, Alb. V. 2004. HTML, JSP dan MySQL. Yogyakarta : Penerbit Andi.

5. Sukmaaji, Anjik dan Rianto. 2008. Jaringan Komputer. Yogyakarta : Penerbit Andi.

6. Prasetyo, Eko. 2008. Pemrograman Web PHP dan MySQL untuk Sistem Informasi Perpustakaan. Yogyakarta : Penerbit Graha Ilmu.

7. Arief, M.Rudyanto. 2011. Pemrograman Web Dinamis Menggunakan PHP dan MySQL. Yogyakarta: Andi.

8. Ramadhan, Arief. 2006. Pemrograman Web Database dengan PHP dan MySQL. Jakarta: Elex Media Komputindo.

9. Septiantono, Tri. Sistem Informasi Perpustakaan Digital. Dimuat pada http://www.konsultanperpustakaan.com/ diakses pada November 2013 